\title{
An Introduction to Program Accreditation in Foreign Language Schools in Turkey
}

\section{Dr. Figen Karaferye}

School of Foreign Languages, Dumlupinar University, Turkey.

\begin{abstract}
The aim of this study is to examine the process of accreditation and the widespreadly preferred accreditation institutions in the preparatory programs of universities in Turkey. Accreditation process in English language teaching requires the involvement of all employees in the process from the upper management level to the lower level. It develops and evaluates language teaching in a multifaceted way as physical facilities, education, academic staff and management. Conducting an action research in a preparatory program which is planning to begin an accreditation process is suggested for further research following this review.
\end{abstract}

Keywords: Accreditation, Language teaching, Preparatory program

\section{Introduction}

With the impact of globalization, information technologies and competitiveness, the higher education sector is heading towards "mass education" and there is an increase in number, size and program diversity in universities. Growth and development in higher education leads universities to institutional quality processes and program / faculty-based accreditation processes (Aqlan, Al-Araidah \& Al-Hawari, 2010).

The necessity of conducting teaching in accordance with accepted quality standards is the subject of research and applications. Universities apply for accreditation to ensure that they meet or exceed international standards of education and training. In addition to accreditation, many different quality control tools can be used to increase institutional effectiveness. Total quality management, six sigma, corporate reporting, benchmarking can be given as examples (Alstete, 2007).

Evaluation processes in higher education, program and field evaluation studies have begun to gain importance since the 1980s. In this sense, the first examples are France, Finland, Holland, England and Denmark. The first country to use accreditation in terms of quality assurance is England (Süngü \& Bayrakçı, 2010). It is after the Bologna Process that accreditation applications increased in universities. With the signing of the Bologna Process in 1999 by higher education representatives from 29 European countries (today 49 countries), the formation of the European Higher Education Area was targeted; a close relationship between national and international higher education systems was established and student and instructor mobility was initiated. Moreover, in 2001 accreditation was proposed as a quality assurance tool at the Bologna management conference

(Haug 2003; Sin, Tavares \& Amaral, 2016).

\section{What is accreditation?}

Accreditation, which provides quality control and assurance in higher education, can be defined as a certified quality assurance in which competence, authority and reliability are approved; the conformity of an institution program to certain standards in the process is inspected / measured (Adelman 1992; Herdman, 2010; Kopelow \& Campbell, 2013). Accreditation also indicates that the program has internationally recognized accreditation standards and the program is introduced to students, other institutions and public in this regard (URL 1).

In a program that is in an accreditation process; topics such as management, academic staff, physical environment features and facilities, library, registration procedures, students, academic calendar, teaching methods, measurement-evaluation, teaching-learning tools and laboratories are subject to a multifaceted study and evaluation. Every topic mentioned here is handled directly in relation to education and training. For example, beyond being a place where books are located when the library is handled, how the library is incorporated into teaching \& learning, how it is used to improve education, how 
many learners can use the library, numbers of books, students and academic staff are handled by their place in practise (Aqlan, Al-Araidah \& Al-Hawari, 2010).

\section{Accreditation process}

Accreditation processes are mostly similar because accrediting institutions/agencies set similar goals and standards. Since the school makes its decision at the point of applying for accreditation, the process requires volunteering. First, the school / program sends a report showing its own status to the accrediting institution/agency that reviews accreditation standards.

Relevant documents such as the standards of the accrediting institutions and the preparation of the institutional reports are usually shared on the institutions' websites or a representative can be contacted for guidance. The accrediting institution and accreditation-candidate school carry out studies in accordance with the accreditation standards and school visits of the authorized person. And after the inspections, the accrediting institution makes the final decision consequently (Prasad \& Bhar, 2010).

One of the most important issues in the accreditation process is the support \& involvement of all employees in the process from the top management to the bottom level similar to the other quality improvement tools' processes. Motivation, interaction and support of all employees in the process from the top to the bottom level are of great importance (Aboelmaged, 2010; Jenicke, Kumar \& Holmes, 2008).

In research on school experiences that are in the process of accreditation or have completed the process, it is seen that academic staff may perceive this process as challenging and exhausting in terms of time and workload due to increased demands. Academicians may find it difficult or unpleasant when they see the accreditation process solely as the extra workload that must be met to provide standards. However, in this process, if they set goals in order to develop themselves professionally and work in order to achieve that instead of working with the perception of "solely following the standards of an outer institution", then there could be a more effective process for both parties (Talbot, 2016). Therefore, encouraging academicians to set objectives for professional as well as institutional goals during the accreditation process can be encouraged.

\section{Accreditation of prep programs in foreign language schools in Turkey}

Universities in Turkey have schools / programs that have completed or are in the process of accreditation. There are various accreditation institutions/agencies with a program-based accreditation authority. These institutions have been accrediting education faculties, pharmacy education programs, science-literature faculties, language and history-geography faculty programs and nursing education programs. For the accreditaton of prep (preparatory) programs in foreign language schools in universities it is seen that CEA and Pearson Assured institutions are mostly preferred. Those two institutions' - the CEA and Pearson Assured - accreditation processes have some differences in some respects, but they also have some similar orientations.

When the background of the standards in English languge teaching is examined it is clearly seen that English language teaching has been explored and developed continuously as a professional field especially since the 1940s. For more effective and efficient language teaching processes, standards have been developed. There are various institutions around the world that work on the development and recognition of those standards. Accreditation UK (administered by British Council and English UK), American Council on the Teaching of Foreign Languages (ACTFL), European Association for Quality Language Services (EAQUALS), International Association of Teachers of English as a Foreign Language (IATEFL), Commission on English Language Program Accreditation (CEA) and TESOL International Association are some of these institutions (Pennington \& Hoekje, 2014).

Prep programs of foreign language schools in universities are increasingly applying to accrediting institutions to meet the international standards in language teaching as well as to be respected for it. When those programs with accreditation processes are examined, it is seen that CEA and Pearson Assured accreditating institutions are mostly preferred in Turkey.

CEA (Commission on English Language Program Accreditation) is an institution that provides accreditation of English language programs and institutions. The CEA Standards for English Language Programs and Institutions comprise 44 individual standards in 11 standards areas. And the accreditation process consists of six steps (URL 2): 


\section{Table 1. CEA Steps in Accreditation Process}

\begin{tabular}{l|l}
$\begin{array}{l}\text { Step 1: Application for } \\
\text { eligibility }\end{array}$ & A school / program applies by completing the documents showing that the eligibility criteria are met. \\
\hline $\begin{array}{l}\text { Step 2: } \\
\text { Workshop }\end{array}$ & $\begin{array}{l}\text { Participation of the school / program representatives in a 2-day workshop (in CEA office abroad or at } \\
\text { TESOL events) to receive guidance on the preparation of the standards and the self-study report. }\end{array}$ \\
\hline $\begin{array}{l}\text { Step 3: } \\
\text { Self-Study plan }\end{array}$ & $\begin{array}{l}\text { One month after the workshop, the site submits a plan for its self-study and CEA staff provides } \\
\text { feedback on the plan. }\end{array}$ \\
\hline $\begin{array}{l}\text { Step 4: } \\
\text { Self-Study report }\end{array}$ & $\begin{array}{l}\text { The school / program explains how it believes it meets each of the 44 CEA standards, documents } \\
\text { compliance, evaluates how well it meets the standards, and recommends areas of improvement in a } \\
\text { self-study report. }\end{array}$ \\
\hline $\begin{array}{l}\text { Step 5: } \\
\text { Site visit }\end{array}$ & $\begin{array}{l}\text { A three-person team reads the self-study report prior to conducting a 3-day on-site visit. The visit } \\
\text { includes class visits, a tour of facilities, and interviews with administrators, faculty, and students in } \\
\text { order to verify the contents of the self-study report. The team applies the CEA Standards in its review } \\
\text { process. The review team-report includes its findings related to each of the 44 CEA standards. The } \\
\text { school receives the report and writes a response to the findings. }\end{array}$ \\
\hline $\begin{array}{l}\text { Step 6: Review by the } \\
\text { Commision }\end{array}$ & $\begin{array}{l}\text { The 13-member CEA Commission uses the self-study report, the review team report, the response } \\
\text { from the site, and a review of finances to make its accreditation decision. For initial accreditation, the } \\
\text { Commission may grant 1-year or 5-year accreditation. For re-accreditation, the Commission may grant } \\
1 \text {-year of 10-year accreditation. Sites that receive 1-year accreditation must respond to requirements } \\
\text { before being considered for continued accreditation. }\end{array}$
\end{tabular}

In the first step of CEA accreditation application, information of those subjects is prepared in a report (CEA Standards for English Language Programs and Institutions, 2016):

Mission of the program/school;

Informational materials:

Introductory information about the program/school e. g. academic calendar, website and other marketing materials.

Curriculum:

Provide a curriculum overview that includes course objectives and student learning outcomes for all courses and levels.

Faculty:

Submit a document describing the general requirements for faculty hiring and a list of current staff showing their qualities.

Facilities:

Provide materials showing the facilities at which courses are offered.

Administrative structure:

Submit an organizational chart showing the lines of reporting within the program and its outer operational relationship.

Student services:

List services available to students, such as counseling and advising, housing, health insurance,social and recreational activities.

Other

Provide documents showing evidence of student enrollment for the past three instructional periods.

Pearson Assured (formerly Edexcel Assured), is an independent organization with training or learning programmes designed for in-house delivery and assessment. Similar to the CEA, first the school / program needs to supply evidence to support their quality systems against each objective of the Pearson Assured. Then the Quality Advisors of the organization carry out very thorough assessments before awarding Pearson Assured status. The accreditation process is consisted of four steps (URL 3): 
Table 2. Pearson Assured Steps in Accreditation Process

\begin{tabular}{l|l} 
Step 1 & Contact the local representative. \\
\hline Step 2 & $\begin{array}{l}\text { The relevant Pearson Assured Guidance and Policy Documents are sent to the school / program, they } \\
\text { are completed and returned including the application form. }\end{array}$ \\
\hline Step 3 & A Quality Advisor visits the site to conduct a review of the quality management system. \\
\hline Step 4 & $\begin{array}{l}\text { If all quality measures are met, the program will receive Pearson Assured Status for } 1 \text { year, as well as } \\
\text { marketing information and files for using the Pearson logo. However, if not all quality measures are met, } \\
\text { Pearson Assured works with the school to improve quality systems and a second site visit is arranged. }\end{array}$
\end{tabular}

Once Pearson Assured Status is received, it is valid for 1 year. At the end of the year, a different Quality Advisor visits the site to inspect whether quality standards are still being maintained. If there are problematic things in the system, they are resolved. However, if they cannot still be resolved, Pearson Assured has the right not to award the status or to withdraw the Pearson Assured brand if serious quality issues are found. The topics to which the Pearson Assured determines the quality objectives of the school / program to be accredited are listed below. A detailed report on the sub-topics regarding the framework of these topics is required to be prepared by the applicant school / program (Pearson Assured Handbook, 2016 ):

Managing the organisation:

The organisation structure, staff resources (roles and team-working), physical resources and administrative systems.

Managing learning/training:

Design of education/training, maintaining and improving quality, learner/trainee recruitment, malpractice, appeals and complaints.

Managing assessment (if applicable).

Even though the CEA and Pearson Assured accreditation processes differ in some respects, they have similar orientations on topics such as education, physical facilities, academic staff and management.

\section{Conclusion and Further Research}

In the twenty-first century, universities have become massive with the influence of globalization, information technologies and competitiveness, and they have a much more interactive structure than they had in the past. It is getting much more important to apply internationally accepted education and training standards. Therefore, the use of quality improvement tools such as accreditation is increasing in a variety of programs and schools/faculties.

The effectiveness and efficiency of teaching English is very important both in Turkey and in the world. Thus, the application of English language teaching at internationally recognized standards and the fact that the school has a reputation in this respect is leading to an increasing number of school accreditations.

In this study, the concept of accreditation is dealt with and two different accreditation institutions, which are widely preferred in the preparatory programs of universities in Turkey, are examined. Following this review, an investigation of how the accreditation process is experienced in an English preparatory program, which will start the accreditation process, is suggested through an action research method. This method is often used by researchers in the field of education to find solutions to contingent problems or to improve their situation (Beyhan, 2013; Glesne, 2013).

In this way, the process of accreditation process will be discussed such as how the unit passed through the process, the place / role of the academicians in the work done, the emerging problems and solutions, and the communication processes among the academicians themselves and with the administrators in the process. It is believed that by carrying out an action research method in the process of accreditation as a quality development tool it will be possible to look at the process critically, to identify possible problems and solutions in the process, and to improve the institution itself. Moreover, the study can constitute an application sample for the institutions that will start the accreditation process by transfering these experiences. 


\section{References}

[1] Aboelmaged, M. G. (2010). Six sigma quality: a structured review and implications for future

research. International Journal of Quality \& Reliability Management, 27 (3), 268-317.

[2] Adelman, C. (1992). Accreditation. B. R. Clarke \& G. Neave (Eds. ), In The Encyclopedia of Higher Education (p. 1313-1318) Vol: 2. Oxford: Pergamon Press.

[3] Alstete, J. W. (2007). Managing internal revitalization and public respect. New York: Palgrave Macmillan.

[4] Aqlan, F., Al-Araidah, O. \& Al-Hawari, T. (2010). Quality assurance and accreditation of engineering education in Jordan. European Journal of Engineering Education, 35 (3), 311-323.

[5] Beyhan, A. (2013). Eğitim örgütlerinde eylem araştırması. Bilgisayar ve Eğitim Araştırmaları Dergisi, 1 (2), 65-89.

[6] CEA Standards for English Language Programs and Institutions 2016. Access link: http://www. ceaaccredit. org/images/2016_CEA_Standards. pdf

[7] Glesne, C. (2013). Nitel araştırmaya giriş. (Translators: A. Ersoy \& P. Yalçınoğlu). Ankara:

[8] Anı Yayıncılık.

[9] Haug, G. (2003). Quality assurance/accreditation in the emerging european higher education area: a possible scenario for the future. European Journal of Education, 38 (3), 229-241.

[10] Herdman, E. A. (2010). Akreditasyon süreci. (Translator: D. Sepit). Hemşirelikte Eğitim ve Araştırma Dergisi, 7 (2), 3-4.

[11] Jenicke, L. O., Kumar, A., Holmes, M. C. (2008). A framework for applying Six Sigma improvement methodology in an academic environment, The TQM Journal, 20 (5), 453- 462.

[12] Kopelow, M. \& Campbell, C. (2013). The benefits of accrediting institutions and organisations as providers of continuing professional education, Journal of European CME, 2 (1), 10-14.

[13] Pearson Assured Handbook 2016. Access link: http://qualifications. com/content/dam/pdf/pearson-assured/PA-Assured- Handbook-2016. pdf

[14] Pennington, M. C. \& Hoekje, B. J. (2014). Framing English language teaching. System, 46,

[15] Prasad, G. \& Bhar, C. (2010). Accreditation system for technical education programmes in India: a critical review. European Journal of Engineering Education, 35 (2), 187-213.

[16] Sin, C., Tavares, O.\& Amaral, A. (2016). The impact of programme accreditation on Portuguese higher education provision. Assessment \& Evaluation in Higher 1203860.

[17] Süngü, H. \& Bayrakçı, M. (2010). Bolonya süreci sonrası yükseköğretimde akreditasyon çalışmaları. Türk Eğitim Bilimleri Dergisi, 8 (4), 895-912.

[18] Talbot, D. (2016). Evidence for no-one: standards, accreditation, and transformed teaching work. Teaching and Teacher Education, 58, 80-89.

[19] URL 1. http://www. apa. org/ed/accreditation/about/about-accreditation. aspx

[20] URL 2. http://www. cea-accredit. org/

[21] URL 3. http://qualifications. pearson. com/en/qualifications/pearson-assured. html 